\title{
Nutrient accumulation in the shoots of physic nut grown in two edaphoclimatic conditions
}

\section{Acúmulo de nutrientes na parte aérea do pinhão-manso em duas condições edafoclimáticas}

\author{
Sávio Coelho Magalhães ${ }^{1}$; Enilson de Barros Silva²; Evander Alves Ferreira ${ }^{3}$; \\ Thassio de Menezes Reis ${ }^{1}$; Gustavo Antônio Mendes Pereira ${ }^{4 *}$ \\ Filipe Vieira Araújo ${ }^{1}$; Tânia Pires da Silva²
}

\begin{abstract}
'The possibility of using physic nut oil as an alternative energy source indicates that it is necessary to carry out studies concerning the absorption and accumulation of nutrients in the distinct phases of development of the crop for the appropriate management of fertilizer application. Given this information, this study aimed to evaluate the accumulation of nutrients in the shoots of physic nut plants, as well as to identify critical nutrient uptake by this crop. The experiments were set up independently in two different locations, from May 2010 to March 2013, and using the same procedures. The locations were characterized as follows: Rhodic Hapludox in the municipality of Curvelo, MG; Typic Quartzipsamment in the municipality of Diamantina, MG. The experiments were conducted in a randomized block design with three replicates, the treatments being the evaluation times of the physic nut plants in both experiments. The collection times were every 30 days from planting of the seedlings in the field for a period of 1,036 days, corresponding to 36 evaluations. After collection, the samples were prepared and submitted to chemical analysis of the nutrient concentration of the plant material. The concentrations were reported as nutrient content of the leaves, stems and fruit of physic nut plants. According to the results, it can be concluded that nutrient accumulation was higher in the edaphoclimatic conditions of Curvelo compared to the conditions of Diamantina. The concentration of macronutrients was in the following order: $\mathrm{K}>\mathrm{Ca}>\mathrm{N}>\mathrm{P}>\mathrm{S}>\mathrm{Mg}$ in Diamantina and $\mathrm{N}>\mathrm{Ca}>\mathrm{K}>\mathrm{P}>\mathrm{Mg}>\mathrm{S}$ in Curvelo. Accumulation of micronutrients in the shoots at 1036 days after planting physic nut seedlings in the field was in the following order: $\mathrm{Mn}>\mathrm{B}>\mathrm{Fe}>\mathrm{Zn}>\mathrm{Cu}$ in Diamantina and $\mathrm{Mn}>\mathrm{Fe}>\mathrm{B}>\mathrm{Zn}>\mathrm{Cu}$ in Curvelo.
\end{abstract}

Key words: Nutrition. Absorption. Jatropha curcas L.

\section{Resumo}

Com a possibilidade de utilização do óleo do pinhão-manso como uma alternativa energética, tem-se a necessidade de realizar estudos referentes à absorção e acúmulo de nutrientes nas diferentes fases de desenvolvimento da cultura para manejo adequado da adubação. Diante do exposto, objetivou-se com esse trabalho avaliar o acúmulo de nutrientes na parte aérea do pinhão-manso, bem como, identificar as fazes críticas de absorção de nutrientes por parte dessa cultura. Os experimentos foram montados

\footnotetext{
1 Discentes, Universidade Federal dos Vales dos Jequitinhonha e Mucuri, UFVJM, Diamantina, MG, Brasil. E-mail: saviocoelho9@ hotmail.com; thassiomenezes@yahoo.com.br; fillipe.vieira10@gmail.com

2 Profs., UFVJM, Diamantina, MG, Brasil. E-mail: enilson.barros.silva@gmail.com; tania.pires@ufvjm.edu.br

3 Pesquisador, UFVJM, Diamantina, MG, Brasil. E-mail: evanderalves@gmail.com

4 Pesquisador, Universidade Federal de Viçosa, UFV, Viçosa, MG, Brasil. E-mail: gustavogamp@hotmail.com

Author for correpondence
}

Received: Aug. 14, 2017 - Approved: Mar. 21, 2018 
independentemente, onde foram utilizados os mesmos procedimentos, no período de maio de 2010 a março de 2013 em locais distintos caracterizados a seguir: Latossolo Vermelho distrófico no município de Curvelo, MG, e o outro, em Neossolo Quartzarênico Órtico típico no município de Diamantina, MG. Os experimentos foram conduzidos em delineamento experimental em blocos casualizados com três repetições, sendo os tratamentos as épocas de avaliação das plantas de pinhão-manso para ambos os experimentos. As épocas de coletas foram a cada 30 dias a partir do plantio das mudas no campo num período de 1.036 dias que corresponderam a 36 avaliações. Após a coleta, as amostras foram preparadas e submetidas às análises químicas do material vegetal dos teores de nutrientes. Os teores foram convertidos em conteúdo de nutrientes nas folhas, caules e frutos das plantas de pinhão-manso. De acordo com os resultados, foi possível concluir que o acúmulo de nutriente foi maior nas condições edafoclimáticas de Curvelo em relação às condições de Diamantina e a sequência de extração para os macronutrientes foi, $\mathrm{K}>\mathrm{Ca}>\mathrm{N}>\mathrm{P}>\mathrm{S}>\mathrm{Mg}$ em Diamantina e $\mathrm{N}>\mathrm{Ca}>\mathrm{K}>\mathrm{P}>\mathrm{Mg}>\mathrm{S}$ em Curvelo. Para os micronutrientes a ordem de acúmulo foi, $\mathrm{Mn}>\mathrm{B}>\mathrm{Fe}>\mathrm{Zn}>\mathrm{Cu}$ em Diamantina e $\mathrm{Mn}>\mathrm{Fe}>\mathrm{B}>\mathrm{Zn}>\mathrm{Cu}$ em Curvelo, na parte aérea, aos 1.036 dias após o plantio das mudas de pinhão-manso no campo.

Palavras-chave: Nutrição. Absorção. Jatropha curcas L.

\section{Introduction}

Research into biodiesel production and its development, encompassing the complete study of nine native oilseeds in Minas Gerais, began in 1980. Among the oleaginous plants, physic nut (Jatropha curcas L.) has been highlighted as a rustic, perennial plant adapted to a wide range of environmental, soil and climatic conditions. This plant is considered to be tolerant to drought and resistant to attack by pests, diseases and herbivores.

The physic nut plant is characterized as a perennial species of the Euphorbiaceae family, which is shrub-sized and presents rapid growth, originating from Central America but growing spontaneously in several regions of Brazil (LAVIOLA; DIAS, 2008). Its cultivation aroused economic interest after the discovery of high oil content of its seeds ( 33 to $38 \%$ oil), which represents between 53 and $79 \%$ of the weight of its fruit, and because it is a rustic plant adapted to diverse soil and climatic conditions (LIMA et al., 2011a). Its oil is not edible and, therefore, would not be diverted to human food. For this reason, particular attention has been given to this species with regard to biodiesel production, and it has the potentially to be used in the production of oil from marginal areas without competing with crops for food purposes (ANDRÉO-SOUZA et al., 2010).
In a short space of time, physic nut projects began in Brazil, India, Mexico, Nicaragua and other countries, some of them supported by supported by international development agencies. Some countries managed to complete projects, but in other countries projected stopped early, such as in the case of Brazil which now seeks to make up for lost time.

Study of the accumulation of dry mass and absorption of nutrients according to the phenological stage of the plant provides information on the period during which plants absorb nutrients in greater proportions and, at the same time, indicates the most propitious time for addition of nutrients in forms readily available to plants. Although the accumulation of dry mass and nutrients is affected by climate, cultivar and cropping systems, 'nutrients are generally absorbed according to the stage of the growth cycle and the translocation in the plant (NOVAIS et al., 2007). The amount and intensity of nutrient uptake by plants occur as a function of the intrinsic characteristics of the organism and external factors that condition the process.

For a given species, the ability to remove nutrients from the soil and the required amounts varies, not only with the cultivar, but also with the degree of competition. Environmental fluctuations, such as temperature and soil moisture, can affect the nutrient content of the leaves considerably. These factors influence both the availability and 
uptake of nutrients by the roots and, consequently, the shoot growth (NOVAIS et al., 2007). On the other hand, the accumulation and distribution of mineral nutrients in the plant depends on its stage of development. At a given moment, the various organs of a plant may be at different stages of development, which will consequently influence their mineral composition (TAIZ; ZEIGER, 2013). The optimal curve of nutrient consumption should define the dose of nutrient to be applied, avoiding possible deficiency or excessive intake; in the latter situation, the plant absorbs more nutrients than it requires and the excessive amount is not reflected by increased productivity.

Most of the dry weight of a vegetable consists of organic materials resulting from photosynthesis and subsequent processes. The essential nutrients, that is the nutritional elements most plants need to complete their cycle, are: $\mathrm{C}, \mathrm{O}$ and $\mathrm{H}$ (provided by air and water); N, P and K (primary macronutrients); $\mathrm{Ca}, \mathrm{Mg}$ and $\mathrm{S}$ (secondary macronutrients) and $\mathrm{B}, \mathrm{Cu}, \mathrm{Fe}, \mathrm{Mn}, \mathrm{Mo}$ and $\mathrm{Zn}$ (micronutrients). The adequate supply of each nutrient at each stage of crop development is essential for optimal growth at all stages (RITCHIE et al., 2003).

Application of fertilizer is one of the main management practices used to increase the productivity and profitability of a crop. It is possible to increase production of jatropha plants using this technique. However, currently there is insufficient information available to make scientifically-based recommendations for fertilizer application due to the scarcity of studies on the behavior of this species.

In view of this, this study aimed to evaluate the accumulation of nutrients in the shoot of the physic nut plant, as well as to identify the critical phases of nutrient absorption in this crop.

\section{Materials and Methods}

Independent experiments were carried out following the same procedures, from May 2010 to March 2013, at two distinct locations. The first site was characterized by Typic Quartzipsamment (Neossolo Quartzarênico in Brazilian classification) and was located at JK Campus of the UFVJM in the municipality of Diamantina (MG), located in the Alto do Vale do Jequitinhonha; $18.15^{\circ}$ latitude (S) and $43.36^{\circ}$ longitude (W. Grw.). Average annual rainfall was $1082 \mathrm{~mm}$, average temperature 19.4 ${ }^{\circ} \mathrm{C}$ and average altitude $1250 \mathrm{~m}$. The second site was characterized by Rhodic Hapludox (Latossolo Vermelho distrofíco in Brazilian classification) under Cerrado vegetation and located at the Experimental Farm of the Moura of the Federal University of the Jequitinhonha and Mucuri Valleys (UFVJM) in the municipality of Curvelo (MG), located in the Minas Geographic Center; $18^{\circ} 45^{\prime}$ latitude (S) and $44^{\circ} 25^{\prime}$ longitude (W. Grw.). Average annual rainfall was $900 \mathrm{~mm}$, average temperature $22.4{ }^{\circ} \mathrm{C}$ and altitude $633 \mathrm{~m}$. Chemical and soil texture analyses were performed according to Silva (2009).

The production of physic nut seedlings was carried out in the greenhouse of the Department of Agronomy of the UFVJM in Diamantina (MG), using seeds from a plant population supplied by the company EPAMIG/CTNM in Nova Porteirinha (MG). The physic nut seedlings were planted planted at the start of the experiments on $05 / 25 / 2010$, with a spacing of $2.5 \mathrm{~m}$ between rows and $2.0 \mathrm{~m}$ between plants, in pits sized $0.3 \times 0.3 \times 0.3 \mathrm{~m}$, at a density of 2000 plants per ha. The plants were $0,12 \mathrm{~m}$ in height and $12 \mathrm{~mm}$ in diameter of the lap, besides two pairs of definitive leaves.

'The need for liming was based on soil chemical analysis and this was performed using dolomitic limestone to raise the saturation by $50 \%$ bases, according to the base saturation method (ALVAREZ; RIBEIRO, 1999) (Table 1). Fertilizer application rate at planting was $150 \mathrm{~kg} \mathrm{P}_{2} \mathrm{O}_{5}$ per ha in the form of single superphosphate and $150 \mathrm{~g}$ of dolomitic limestone in the planting pit. The $\mathrm{N}$ and $\mathrm{K}$ coverage was $50 \mathrm{~kg} \mathrm{~N}$ (ammonium sulphate) and $100 \mathrm{~kg}$ $\mathrm{K}_{2} \mathrm{O}$ (potassium chloride) per ha, divided into three applications from December to February in the 
years 2010/11,2011/12 and 2012/13. Application of micronutrient fertilizer was carried out in the first application of $\mathrm{N}$ and $\mathrm{K}$ at both planting sites, where $1 \mathrm{~kg}$ of B (borax) and $2 \mathrm{~kg}$ of Zn (zinc sulphate) per ha were applied.

The experiments were conducted in a randomized block design with three replicates, the treatments being the evaluation times of the physic nut plants for both experiments. The experimental plot was composed of 12 plants, using the two central plants to carry out the evaluations. The sampling times were approximately every 30 days, from planting the seedlings in the field for some period of 1036 days, corresponding to 36 evaluations. Two central plants of the useful plot were collected. Each sample was composed of two plants at each sampling time.

Table 1. Chemical and textural attributes of soils prior to the implementation of the experiments.

\begin{tabular}{cccc}
\hline Attribute & Unity & TQ & $\mathrm{RH}$ \\
\hline $\mathrm{pH}_{\text {water }}$ & - & 5 & 5.8 \\
$\mathrm{P}$ & $\mathrm{mg} \mathrm{kg}^{-1}$ & 1.1 & 1.4 \\
$\mathrm{~K}$ & ${\mathrm{mmol} \mathrm{kg}^{-1}}_{\mathrm{c}}$ & 0.3 & 1.8 \\
$\mathrm{Ca}$ & $\mathrm{mmol} \mathrm{kg-1}_{\mathrm{c}}$ & 4 & 23 \\
$\mathrm{Mg}$ & $\mathrm{mmol}_{\mathrm{c}} \mathrm{kg}^{-1}$ & 2 & 11 \\
$\mathrm{Al}$ & $\mathrm{mmol}_{\mathrm{c}} \mathrm{kg}^{-1}$ & 5 & 7 \\
$\mathrm{~T}$ & $\mathrm{mmol}_{\mathrm{c}} \mathrm{kg}^{-1}$ & 57.3 & 83.3 \\
$\mathrm{M}$ & $\%$ & 44 & 16.4 \\
$\mathrm{~V}$ & $\%$ & 11 & 43 \\
$\mathrm{CO}$ & $\mathrm{g} \mathrm{kg}^{-1}$ & 4.6 & 17.4 \\
$\mathrm{Sand}$ & $\mathrm{g} \mathrm{kg}^{-1}$ & 870 & 90 \\
$\mathrm{Silt}$ & $\mathrm{g} \mathrm{kg}^{-1}$ & 70 & 450 \\
$\mathrm{Clay}$ & $\mathrm{g} \mathrm{kg}^{-1}$ & 60 & 460 \\
\hline
\end{tabular}

pH Water: Ratio: water 1: 2.5. P and $\mathrm{K}$ : $\mathrm{Mehlich}^{-1}$ extractor. $\mathrm{Ca}, \mathrm{Mg}$ and $\mathrm{Al}$ : extractor $\mathrm{KCl} 1 \mathrm{~mol} \mathrm{~L}^{-1}$. T: Cation exchange capacity at pH 7.0. m: saturation of aluminum. V: Base Saturation. CO: Organic carbon by the Walkey-Black method. Sand, silt and clay: Pipette method. TQ: Typic Quartzipsamment. RH: Rhodic Hapludox.

After collection, the plants were separated into the vegetative part (leaves and stem) and the reproductive part (fruit). The plant parts were washed in distilled water. The different plant parts were then packed in paper bags and placed in an oven with forced air circulation and kept at $65{ }^{\circ} \mathrm{C}$. The drying time was determined by weighing the samples until constant weight was reached. After drying, each sample was weighed using an analytical balance to determine the dry mass accumulated in the plant part (leaves, stems and fruits). The samples were then ground in a Willey mill and subjected to the chemical analysis to determine the nutrient concentration, according to the methodology described by Malavolta et al. (1997). The results were expressed as nutrient content of the dry mass of the physic nut plant parts.

The data were submitted to analysis of variance using the $\mathrm{F}$ test. For data that presented significant differences, regression adjustments were applied to the evaluation of the dry mass of leaf, stem, fruit and shoot (leaf + stem + fruit) and nutrient content of the dry mass of each plant part at each cultivation site. 


\section{Results and Discussion}

There was a difference in the accumulation of nutrients in the shoot of the physic nut plants due to the evaluation periods in the two edaphoclimatic conditions (Diamantina and Curvelo) (Table 2). The highest accumulation of nutrients in the physic nut plants was reached at 1,036 days after planting (DAP) in the leaf, stem and shoot, coinciding with the maximum accumulation of dry matter in the plants; at this time-point, there was also greater accumulation of nutrients with conditions at the Curvelo location compared to Diamantina (Table 2). Nutrient absorption occurred in the periods with higher water availability where the greatest growth of the crop was observed. Albuquerque et al. (2009), analyzing the initial growth of the physic nut plant in dry conditions in the northeastern semiarid region, reported rapid growth of the crop in the rainy season; however, in the dry season there was a drastic reduction in its growth rate.

Table 2. Maximum nutrient accumulation in leaves at three growths, stem and shoot periods of physic nut plants and plant age corresponding to the maximum in two edaphoclimatic conditions (Diamantina and Curvelo) in the state of Minas Gerais.

\begin{tabular}{|c|c|c|c|c|c|c|c|c|c|c|}
\hline \multirow{3}{*}{ Nutrients } & \multicolumn{6}{|c|}{ Leaf } & \multirow{2}{*}{\multicolumn{2}{|c|}{ Stem }} & \multirow{2}{*}{\multicolumn{2}{|c|}{ Shoot }} \\
\hline & \multicolumn{2}{|c|}{ First } & \multicolumn{2}{|c|}{ Second } & \multicolumn{2}{|c|}{ Third } & & & & \\
\hline & Days & Value & Days & Value & Days & Value & Days & Value & Days & Value \\
\hline \multicolumn{11}{|c|}{ Diamantina (MG) } \\
\hline $\mathrm{N}$ & 275 & 22.73 & 615 & 14.38 & 1036 & 43.16 & 1036 & 578.97 & 1036 & 609.95 \\
\hline $\mathrm{P}$ & 275 & 13.67 & 620 & 8.35 & 1036 & 23.67 & 1036 & 178.78 & 1036 & 195.97 \\
\hline K & 278 & 75.83 & 617 & 44.01 & 1036 & 129.48 & 1036 & 1362.7 & 1036 & 1458.38 \\
\hline $\mathrm{Ca}$ & 285 & 36.32 & 618 & 26.1 & 1036 & 79.9 & 1036 & 1062.7 & 1036 & 1119.66 \\
\hline $\mathrm{Mg}$ & 287 & 5.83 & 614 & 3.55 & 1036 & 13.07 & 1036 & 108.13 & 1036 & 116.29 \\
\hline S & 267 & 6.96 & 597 & 2.42 & 1036 & 15.54 & 1036 & 138.33 & 1036 & 147.7 \\
\hline B & 276 & 251.15 & 615 & 158.67 & 1036 & 495.33 & 1036 & 5071.55 & 1036 & 5435.62 \\
\hline $\mathrm{Cu}$ & 273 & 6.01 & 635 & 5.82 & 1036 & 13.92 & 1036 & 237.87 & 1036 & 247.22 \\
\hline $\mathrm{Fe}$ & 390 & 189.92 & 616 & 89.5 & 1036 & 281.14 & 1036 & 2505.36 & 1036 & 2708.83 \\
\hline $\mathrm{Mn}$ & 278 & 525.23 & 616 & 321.42 & 1036 & 1003.75 & 1036 & 13341.04 & 1036 & 14005.16 \\
\hline $\mathrm{Zn}$ & 297 & 13,17 & 609 & 8.71 & 1036 & 36.75 & 1036 & 361.78 & 1036 & 385.13 \\
\hline \multicolumn{11}{|c|}{ Curvelo (MG) } \\
\hline $\mathrm{N}$ & 299 & 1215.89 & 653 & 3932.01 & 1022 & 6015.89 & 957 & 17928.58 & 1036 & 26183.35 \\
\hline $\mathrm{P}$ & 296 & 156.18 & 653 & 469.23 & 1022 & 717.67 & 980 & 2455.67 & 1036 & 3305.63 \\
\hline K & 299 & 989.38 & 653 & 2637.47 & 1022 & 4031.56 & 968 & 13512.23 & 1036 & 19244.84 \\
\hline $\mathrm{Ca}$ & 305 & 824.28 & 653 & 2892.24 & 1022 & 4423.28 & 975 & 17118.67 & 1036 & 23038.19 \\
\hline $\mathrm{Mg}$ & 309 & 87.16 & 653 & 307.2 & 1022 & 468.92 & 947 & 1762.38 & 1036 & 2542.32 \\
\hline $\mathrm{S}$ & 300 & 79.6 & 653 & 268.37 & 1022 & 408.87 & 956 & 1292.59 & 1036 & 1966.01 \\
\hline B & 308 & 3990.03 & 653 & 3217.15 & 1022 & 4923.65 & 958 & 16136.26 & 1036 & 22028.75 \\
\hline $\mathrm{Cu}$ & 300 & 223.56 & 653 & 1411.96 & 1022 & 2167.32 & 1000 & 7842 & 1036 & 10129.26 \\
\hline $\mathrm{Fe}$ & 306 & 3363.68 & 653 & 18377.39 & 1022 & 28106.54 & 968 & 94341.76 & 1036 & 131591.1 \\
\hline $\mathrm{Mn}$ & 303 & 6062.49 & 653 & 20462.02 & 1022 & 31279.28 & 996 & 197967 & 1036 & 243728.8 \\
\hline $\mathrm{Zn}$ & 303 & 424.12 & 653 & 1470.23 & 1022 & 2249.14 & 968 & 8540.73 & 1036 & 11731.93 \\
\hline
\end{tabular}

Accumulation of nutrients expressed in $\mathrm{g}$ or $\mathrm{mg} \mathrm{ha}^{-1}$ for macro and micronutrient, respectively. Period of growth of the leaves: First of May/2010 to June/2011, second of November/2011 to June/2012 and the third of November/2012 to March/2013. 
Data on the accumulation of N, P and $\mathrm{K}$ in dry leaf mass (DML), stem (DMS), fruit (DMF) and the shoot (DMSH) of physic nut plants up to 1,036 days after planting the seedlings at the two cultivation sites are presented in Figure 1, with the exception of DMF in Diamantina, where the plants did not fruit until the time of harvest.

Values for $\mathrm{N}$ showed different behavior in terms of its accumulation in the physic nut plants at both sites, being the nutrient found at the third highest content in plants in Diamantina. It was the nutrient most required in plants grown in the municipality of Curvelo for the formation of leaves, stems and shoots, and also for meeting the metabolic demands of fruit in this second location (Table 2). In relation to the greater accumulation in plant parts, $\mathrm{N}$ accumulated in a greater proportion in the stem in relation to the leaves in both experiments. Accumulation reached peak levels in the leaves in the three rainy periods in which leaves were present; subsequent decreases in the accumulated values were due to vegetative rest of the physic nut plants (Table 2).

Figure 1. Accumulation of N, P and $\mathrm{K}$ in dry mass (DM) of leaf, stem, fruit and shoot in physic nut plants under two soil and climatic conditions (Diamantina and Curvelo) from Minas Gerais State, evaluated up to 1,036 days after planting of the seedlings, except for the DM fruit in Diamantina, where the plants did not fruit until the date of harvest.

Diamantina (MG)
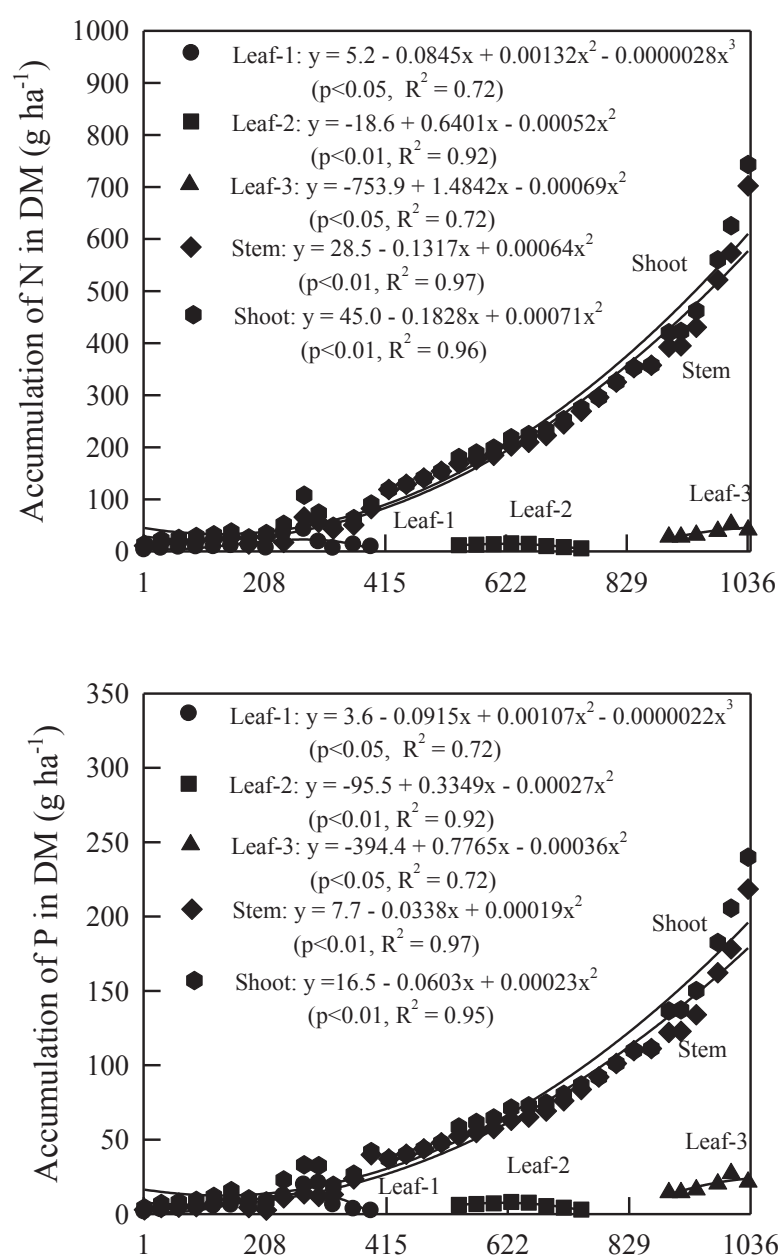

Curvelo (MG)
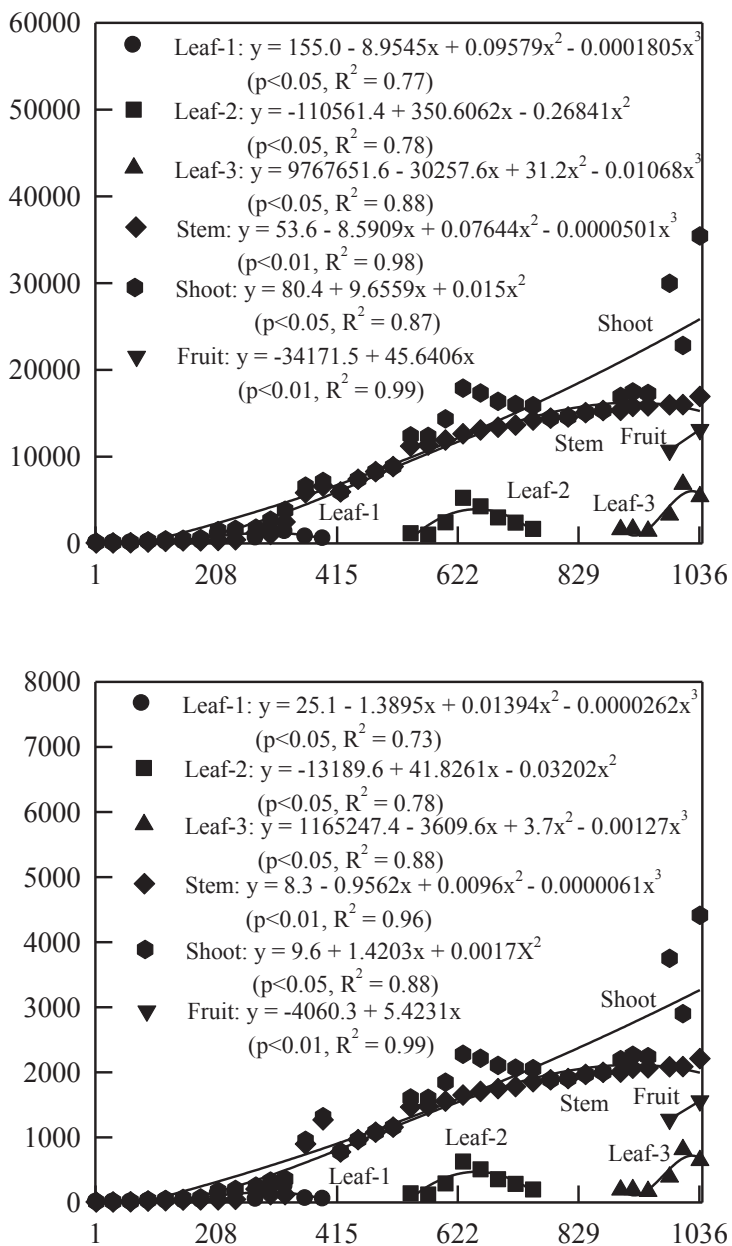

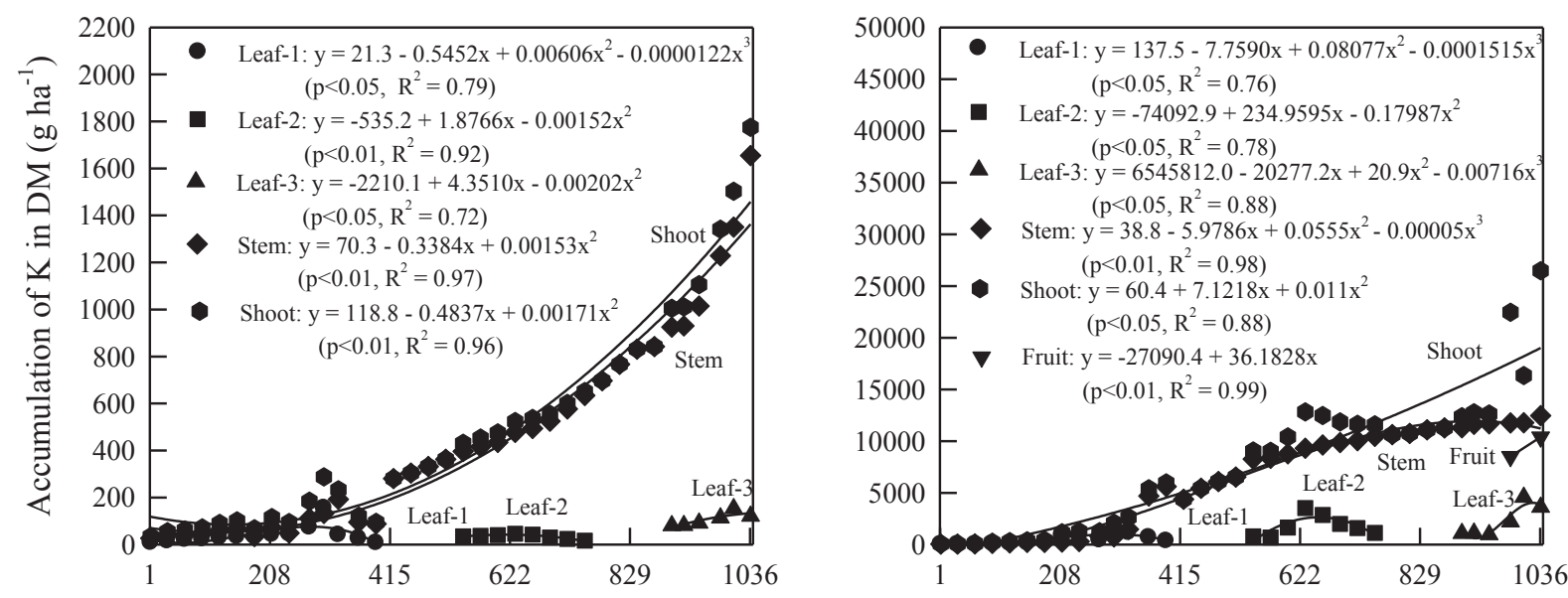

Days after planting

According to Avelar et al. (2008), physic nut is a plant that presents a high growth rate mainly in the first two years of cultivation, with $\mathrm{N}$ being essential for the assimilation of carbon and formation of new organs in the plant (TAIZ; ZEIGER, 2013). Compared to other plants, such as coffee tree (LAVIOLA; DIAS et al., 2008), guava (HAAG et al., 1993) and orange tree (MATTOS JÚNIOR et al., 2003), in the present study, physic nut presented $21.04 \mathrm{~g} \mathrm{~kg}^{-1}$ of $\mathrm{N}$ in the fruits, higher content than those found by these authors. According to Silva et al. (2009), omission of macro and micronutrients for physic nut causes visual symptoms of nutritional deficiency, common to other species. Lima et al. (2011a) found that the nutrients $\mathrm{P}, \mathrm{K}, \mathrm{Cu}$ and $\mathrm{Zn}$ were intensely redistributed from the older leaves to the younger tissues of the physic nut plant, while there was little redistribution of $\mathrm{N}, \mathrm{Ca}, \mathrm{Mg}, \mathrm{Fe}$, and Mn.

$\mathrm{P}$ was the fourth most required nutrient by the crop, showing similar results at both sites (Table 2). Although it was not among the first in terms of its accumulation, it was very limiting, especially during the initial phase of growth of the physic nut. The Brazilian soils showed a low P concentration; in addition, this nutrient was rapidly fixed by the clay fraction, constituted mainly by $\mathrm{Fe}$ and $\mathrm{Al}$ oxides (NOVAIS; SMYTH, 1999). Authors, such as Silva et al. (2007) and Santos et al. (2007), found in their research that physic nut was very responsive to phosphate fertilizer application in the early years of cultivation.

In this way, the supply of P to the jatropha, mainly in the first years of cultivation, must be in a greater quantity than that absorbed by the plant. During cultivation, there was an 'in the area explored by the root system and the efficiency of recovery of $\mathrm{P}$ in the soil increased (PREZOTTI, 2001). The maximum growth of the physic nuta plants was observed with the addition of simple superphosphate to the substrate in doses estimated to be in the range 5 to 8 $\mathrm{kg} \mathrm{m}^{-3}$. According to Lima et al. (2011b), phosphate fertilizer favored the growth mainly of roots and leaf area. According to the same authors, the addition of phosphate fertilizer provided an increase in plant tissue concentration of all macronutrients, except for calcium.

The $\mathrm{K}$ was the element required in greater quantities by the physic nut in Diamantina and the third one with greater element accumulation in Curvelo in the leaves and in the stem in Curvelo in the leaves and in the stem (Table 2). In the fruit, $\mathrm{K}$ was the nutrient that had the highest accumulation with $10395 \mathrm{~g} \mathrm{ha}^{-1}$ at $1036 \mathrm{DAP}$. 
The role of $\mathrm{K}$ is important in the formation of fruits, as it is involved in the transport of photoassimilates in the phloem (TAIZ; ZIEGER, 2013). The deposition of biomass in the fruit is necessarily accompanied by the accumulation of $\mathrm{K}$. In addition, $\mathrm{K}$ is a required nutrient in the activation of several enzymes essential for the synthesis of organic compounds, including starch (TAIZ; ZEGER, 2013).

When studying the redistribution of nutrients in physic nut leaves, Lima et al. (2011b) found that the levels of $\mathrm{K}$ were higher in young leaves with more intense physiological activity, but as these processes reduced, $\mathrm{K}$ was redistributed to other plants organs. According to Pacheco et al. (2009), the stem, besides being a structural organ of the plant, is a reserve organ. In this way, losses of $\mathrm{K}$ during leaf fall are reduced by redistribution.

Theaccumulation ofthesecondarymacronutrients $\mathrm{Ca}, \mathrm{Mg}$ and $\mathrm{S}$ in dry leaf mass (DML), stem (DMS), fruit (DMF) and shoot (DMSH) in physic nut plants up to 1036 days after planting of the seedlings at the two cultivation sites is presented in Figure 2, except for the DMF in Diamantina, where the plants did not fruit until the date of harvest.

Figure 2. Accumulation of $\mathrm{Ca}, \mathrm{Mg}$ and $\mathrm{S}$ in dry mass (DM) of leaf, stem, fruit and shoot in physic nut plants under two soil and climatic conditions (Diamantina and Curvelo) from Minas Gerais State, evaluated up to 1,036 days after planting of the seedlings, except for the DM fruit in Diamantina, where the plants did not fruit until the date of harvest.

Diamantina (MG)
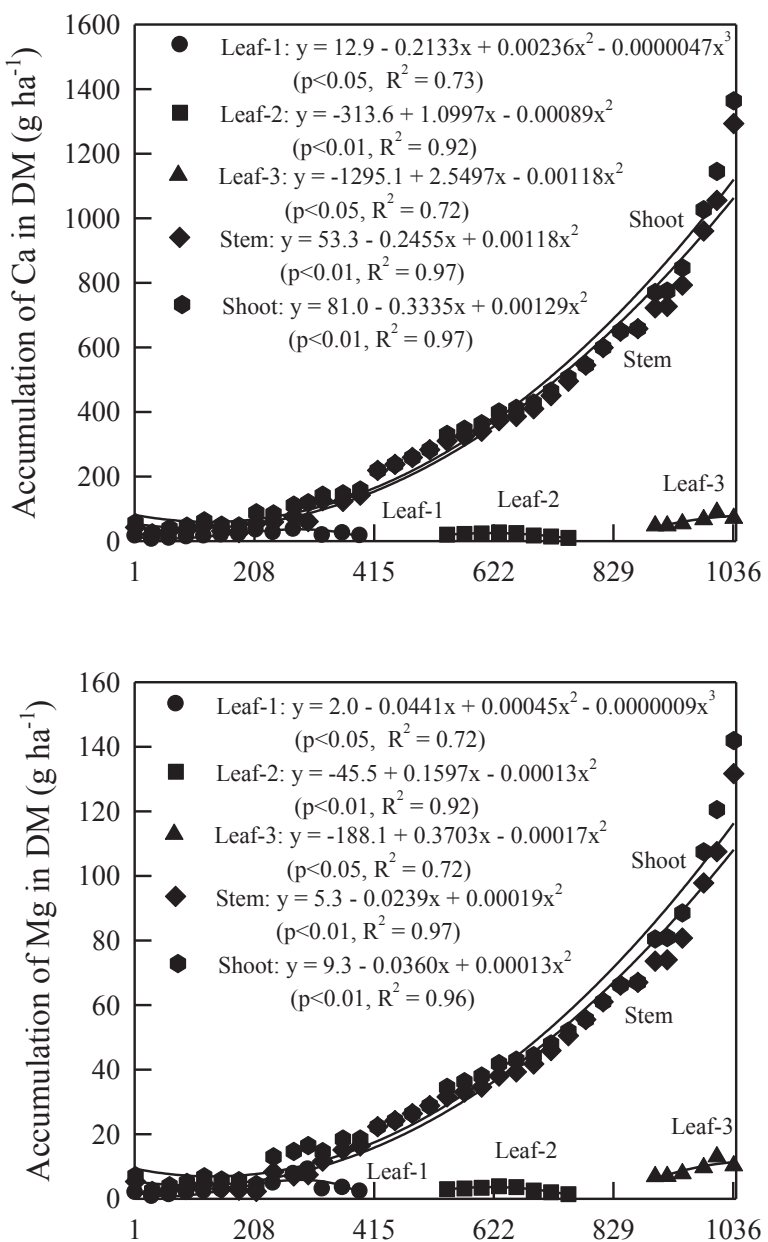

Curvelo (MG)
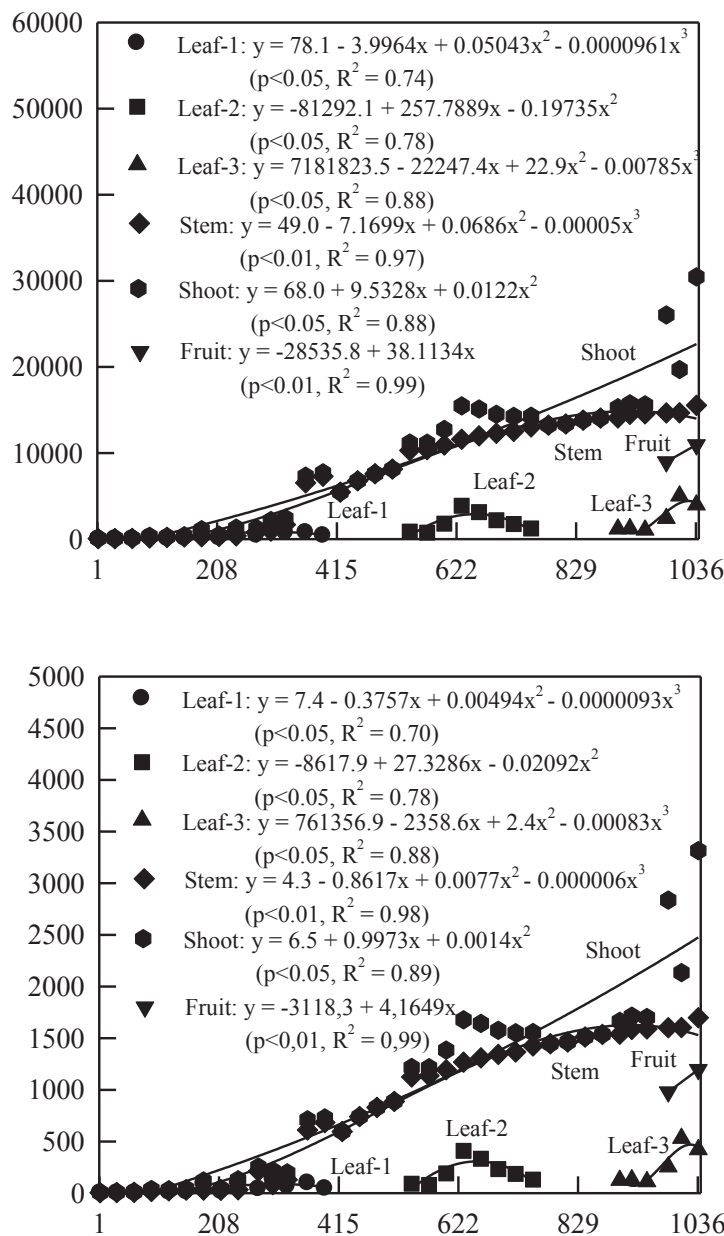

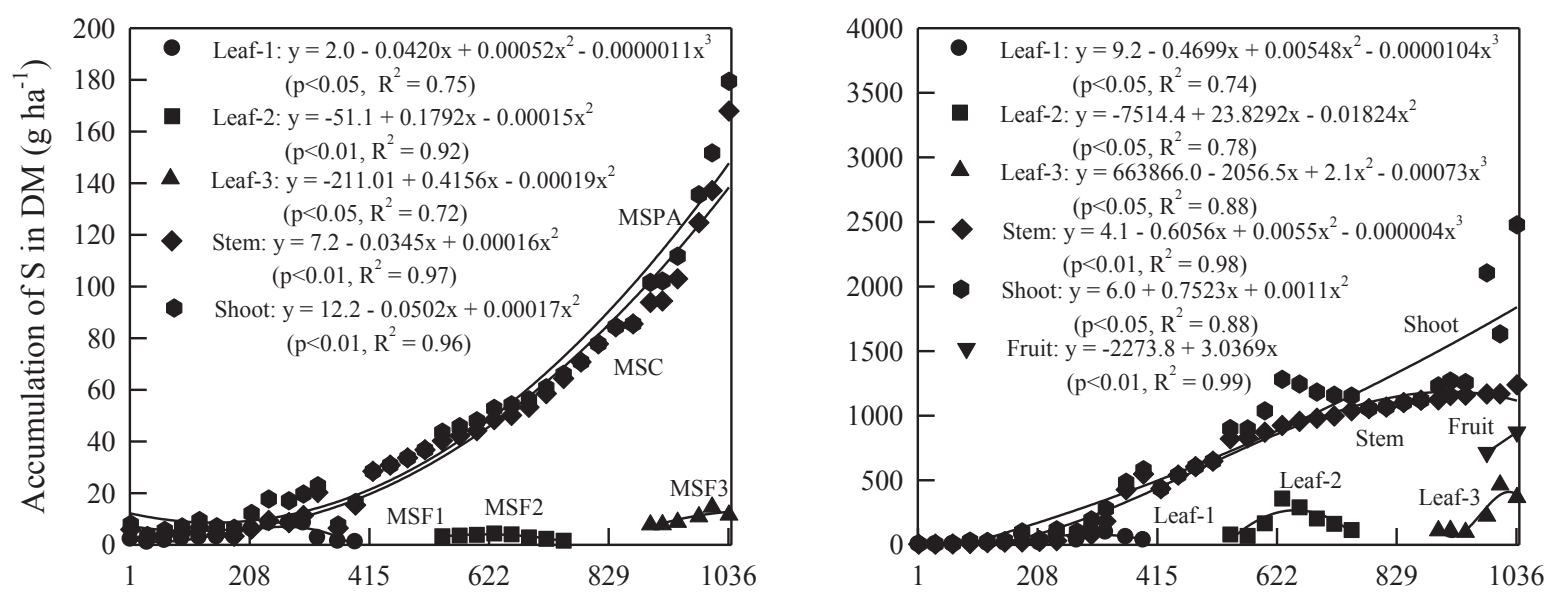

Days after planting

Levels of Ca maintained the same tendency in the two places, with $\mathrm{Ca}$ being the second most demanded nutrient by the physic nut plant in the different plant parts. In the fruit, $\mathrm{Ca}$ presented a concentration very close to that of $\mathrm{K}\left(17.6 \mathrm{~g} \mathrm{~kg}^{-1}\right)$ in Curvelo. Thus, it is important that the soil presents adequate levels of this nutrient so as not to limit plant growth and production, since this nutrient presents low mobility in the plant which reduces its rate of redistribution. In general, it is important that the Ca concentration in the soil is maintained at the optimal range (above $3.5 \mathrm{cmolc} \mathrm{dm}^{-3}$ ), considering a ratio of 4:1 to 3:1 with $\mathrm{Mg}$ (NOVAIS et al., 2007).

$\mathrm{B}$ and $\mathrm{Ca}$ are indispensable for pollen germination, pollen tube growth and, consequently, flower fertilization (TAIZ; ZIEGER, 2013). This also confirms the importance of $\mathrm{Ca}$ in the productive phase of culture.

$\mathrm{Mg}$ accumulation was lower than that of $\mathrm{Ca}$, the accumulation of $\mathrm{Mg}$ was lower than the $\mathrm{Ca}$ accumulation, and $\mathrm{Mg}$ was the last in the nutrient extraction sequence of the plants cultivated in Diamantina with accumulation of $116.3 \mathrm{~g} \mathrm{ha}^{-1}$, and penultimate in Curvelo (2542.3 $\left.\mathrm{g} \mathrm{ha}^{-1}\right)$, only below $\mathrm{S}$, in the shoot of the plant. The stem showed a greater tendency to accumulate $\mathrm{Mg}$ than the leaves (Table 2).
On the other hand, the sulfur presented an inverse behavior to $\mathrm{Mg}$, having the second lowest accumulation in plants cultivated in Diamantina; $\mathrm{S}$ accumulation was low at the beginning of the experiment, intensifying at $415 \mathrm{DAP}$, and reaching maximum accumulation at 1036 DAP (Table 2). In Curvelo, $\mathrm{S}$ was the nutrient with the lowest accumulation, showing slow absorption until 208 DAP and, from that period, an increase in accumulation of this nutrient was observed until the end of the evaluated period.

Accumulation of micronutrients $\mathrm{B}, \mathrm{Cu}, \mathrm{Fe}, \mathrm{Mn}$ and $\mathrm{Zn}$ in leaf dry matter (DML), stem (DMS), fruit (DMF) and shoot (DMSH) in physic nut plants up to 1036 days after planting the seedlings at the two cultivation sites is presented in Figures 3 and 4, except for DMF in Diamantina where the plants did not fruit until the time of harvest.

$\mathrm{B}, \mathrm{Zn}$ and Cuwere the most limitingmicronutrients for the crops. Of these micronutrients, B was the one most required at both sites, with the second highest accumulation in plants cultivated at Diamantina (5435.62 $\mathrm{mg} \mathrm{ha}^{-1}$ ), and the third highest at Curvelo $\left(22028.75 \mathrm{mg} \mathrm{ha}^{-1}\right)$ in the shoot of the physic nut at 1036 DAP (Table 2). The inadequate availability of this nutrient may contribute to reduced productivity, due to a smaller quantity of flowers produced, so the 
quantities supplied and absorbed by the physic nut plants in this study were sufficient to produce good development of the flowers.

$\mathrm{Zn}$ and $\mathrm{Cu}$ presented the same position in the extraction sequence and smaller accumulations in the plants at both sites. 'In shoot of the plant, $\mathrm{Zn}$ accumulation was $385.13 \mathrm{mg} \mathrm{ha}{ }^{-1}$ and 11731.93 $\mathrm{mg} \mathrm{ha}{ }^{-1}$ and $\mathrm{Cu}$ accumulation $247.22 \mathrm{mg} \mathrm{ha}^{-1}$ and 10129.26 $\mathrm{mg} \mathrm{ha}^{-1}$ in Diamantina and Curvelo, respectively (Table 2). Despite the low nutrient accumulation in the plants grown in Diamantina, no nutrient deficiency was observed, and this low concentration of $\mathrm{Zn}$ and $\mathrm{Cu}$ may have been caused by the mobility of these elements in the soil. The fact that this soil presents sandy texture and low levels of organic matter, may have facilitated losses by leaching.

Mn was the micronutrient most accumulated by physic nut plants, presenting total accumulation values of $14005.16 \mathrm{mg} \mathrm{ha}^{-1}$ and $243728.78 \mathrm{mg}$ $\mathrm{ha}^{-1}$ in the shoot of the plants at 1036 DAP in Diamantina and Curvelo, respectively (Table 2). 'Results showing higher requirements for Mn by physic nut plants were also reported by Laviola and Dias (2008) when evaluating leaf content. For the castor bean crop, also from the Euphorbiaceae family, the micronutrient Mn was also the most required (NASCIMENTO et al., 2012).

Figure 3. Accumulation of $\mathrm{B}, \mathrm{Cu}$ and $\mathrm{Fe}$ in dry mass (DM) of leaf, stem, fruit and shoot in physic nut plants under two soil and climatic conditions (Diamantina and Curvelo) from Minas Gerais State, evaluated up to 1,036 days after planting of the seedlings, except for the DM fruit in Diamantina, where the plants did not fruit until the date of harvest.

Diamantina $(\mathrm{MG})$
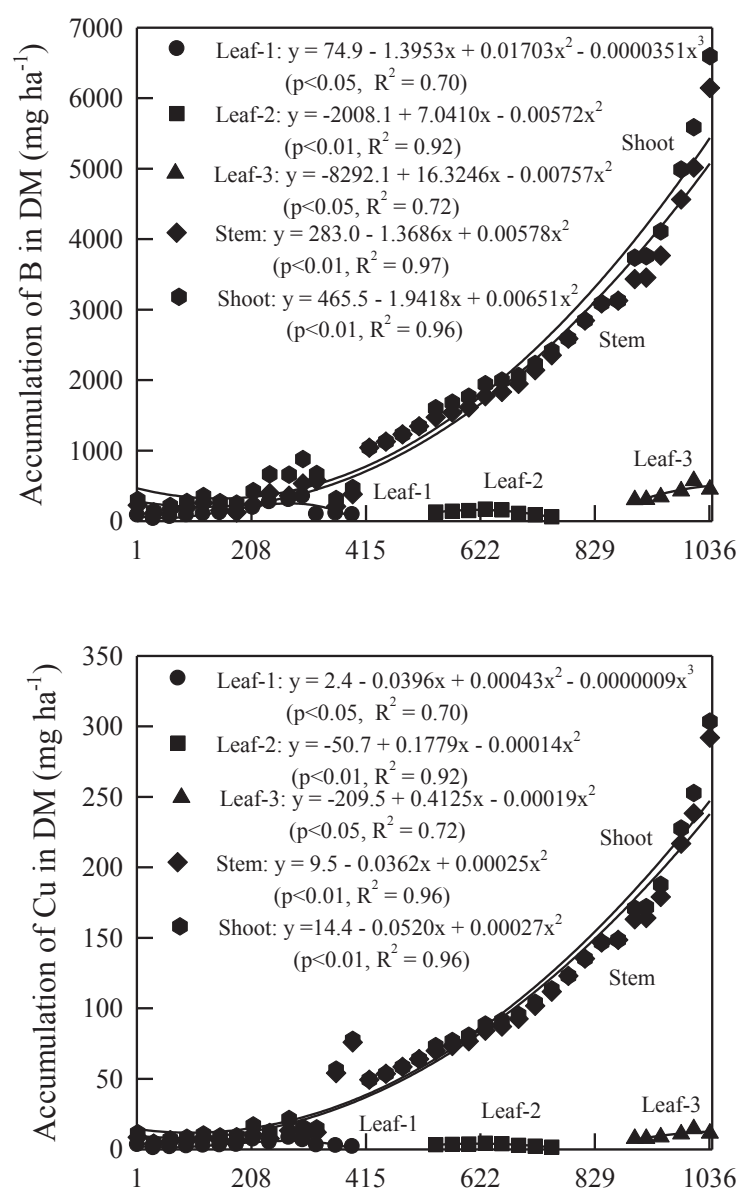

Curvelo (MG)
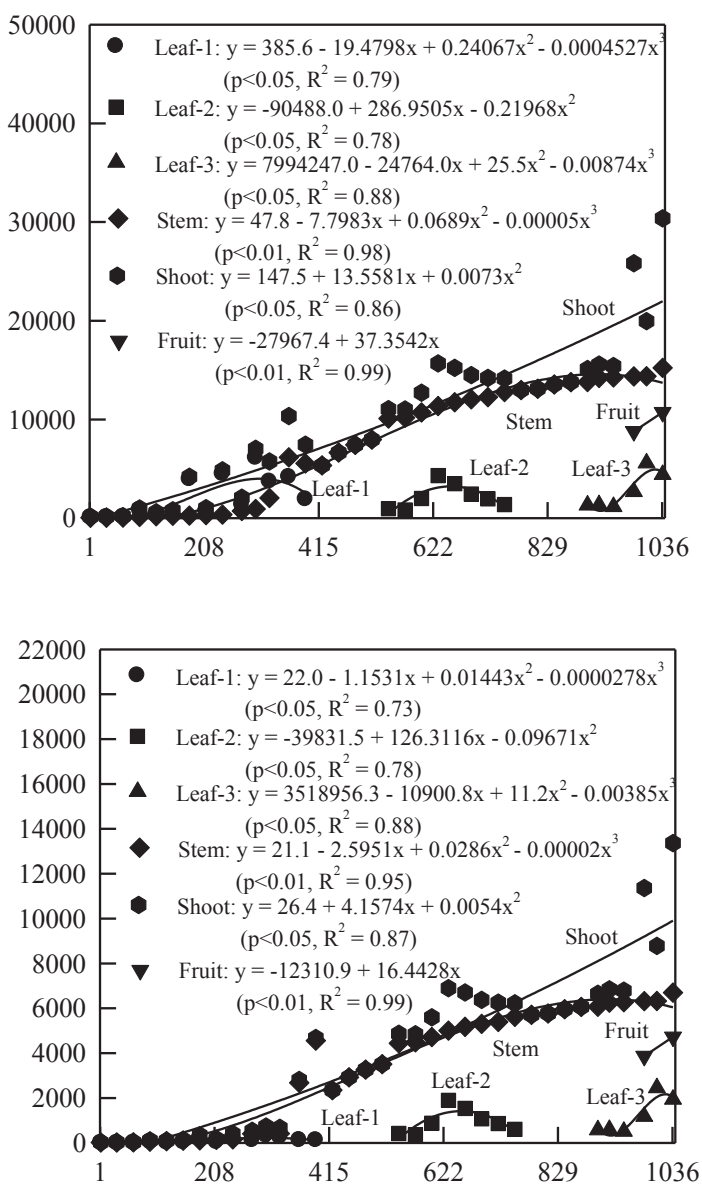

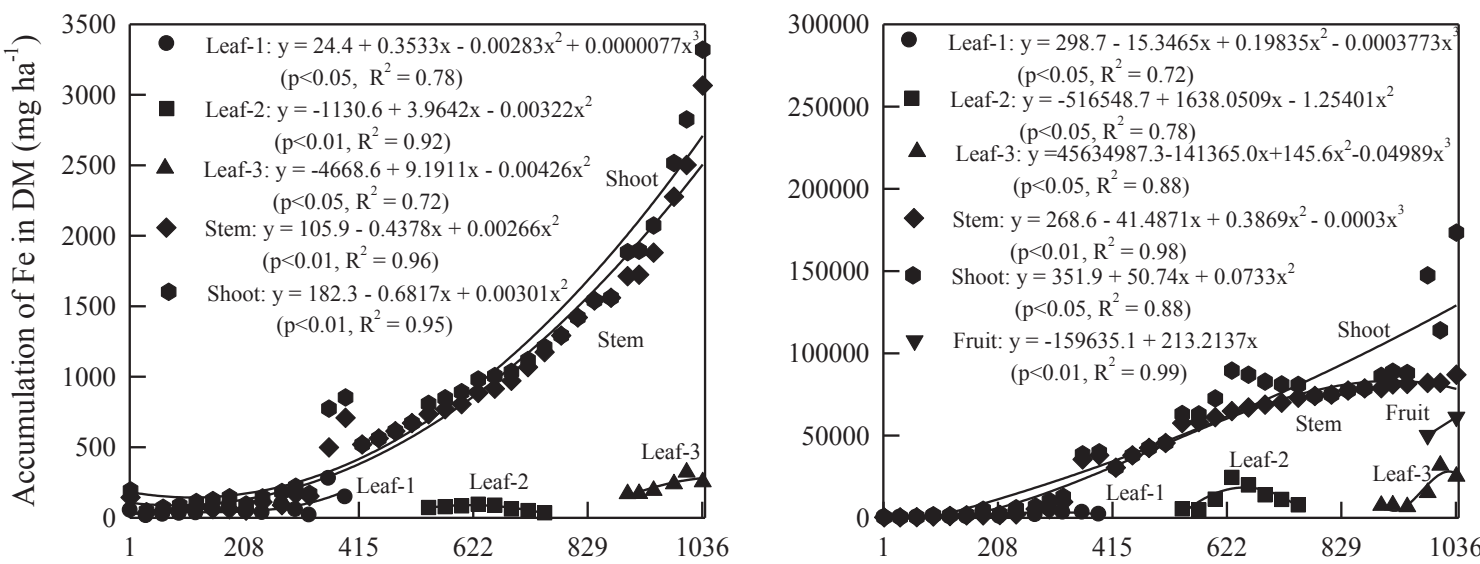

Days after planting

Figure 4. Accumulation of $\mathrm{Mn}$ and $\mathrm{Zn}$ in dry mass (DM) of leaf, stem, fruit and shoot in physic nut plants under two soil and climatic conditions (Diamantina and Curvelo) from Minas Gerais State, evaluated up to 1,036 days after planting of the seedlings, except for the DM fruit in Diamantina, where the plants did not fruit until the date of harvest.
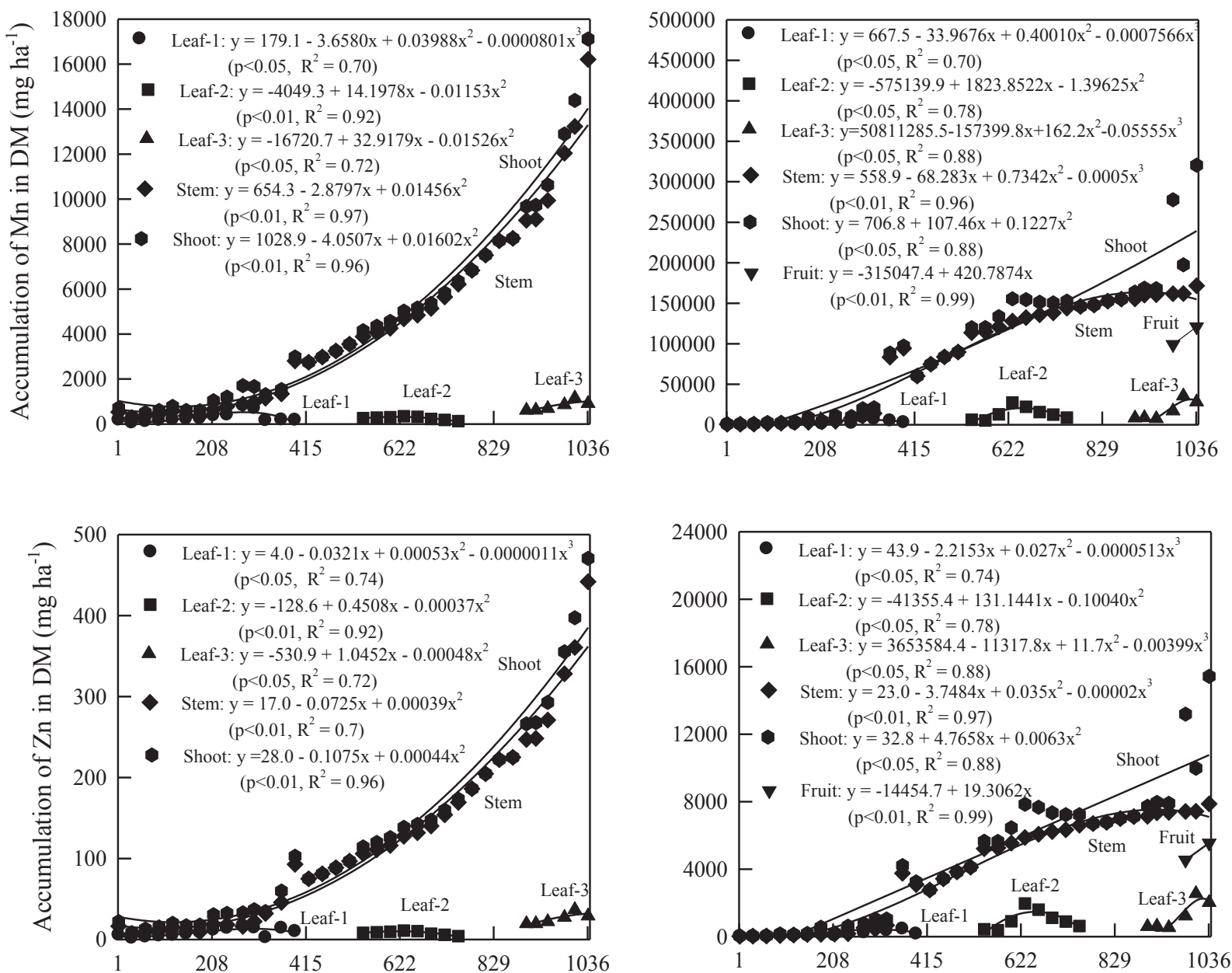

Days after planting 
The values observed for $\mathrm{Fe}$ were inversely related to that observed for $\mathrm{B}$ in the micronutrient extraction sequence in the physic nut plants, being the third element with greater accumulation in the shoot of the plants in Diamantina and the second in Curvelo, with maximum accumulation at 1,036 DAP for both locations (Table 3), in addition to accumulating in larger proportions in the stem in relation to the leaves (Table 2).

The absorption rate for macronutrients showed the same trend for Diamantina and Curvelo, with absorption rates of approximately $0.4 \mathrm{~g} \mathrm{day}^{-1}$ at the beginning of the cultivation, a marked increase up to $208 \mathrm{DAP}$ where rates were higher than $0.8 \mathrm{~g}$ day 1 , followed by stabilization in the absorption rates up to 1036 days of culture (Figure 5).

The micronutrients, $\mathrm{Cu}$ and $\mathrm{Zn}$, in physic nut plants behaved similarly to macronutrients at both sites, but $\mathrm{B}, \mathrm{Fe}$ and $\mathrm{Mn}$ showed differences in absorption rates (Figure 5). The absorption rates of these elements were below $0.4 \mathrm{mg}^{\text {day }^{-1}}$ in Curvelo and close to $0 \mathrm{mg}$ day $^{-1}$ for Diamantina at the beginning of the experiment, with an expressive increase in the absorption rate up to 208 DAP, tending to stabilize until 1036 DAP.

Figure 5. Absorption rate (AR) of nutrients and cumulative growth rate of the crop (CGRC) in physic nut plants under two soil and climatic conditions (Diamantina and Curvelo) from Minas Gerais State, evaluated up to 1,036 days after planting of the seedlings.
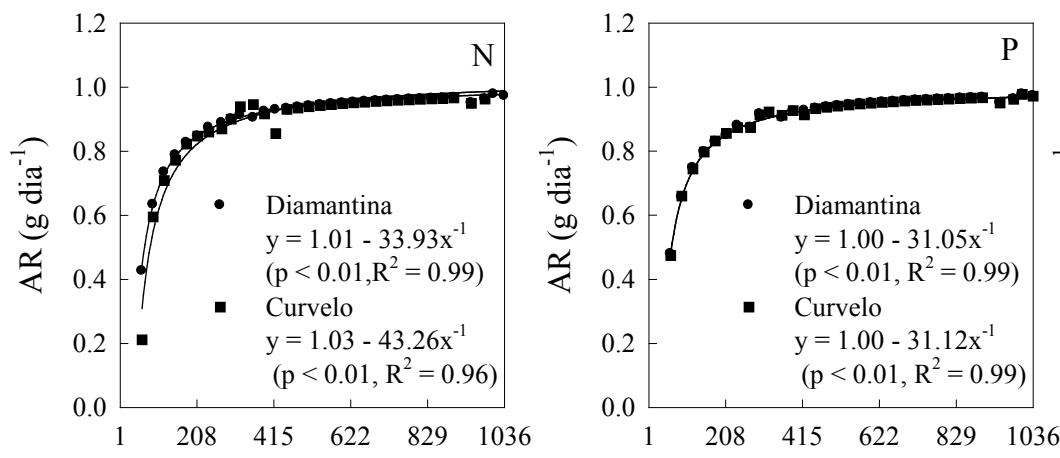

Days after planting

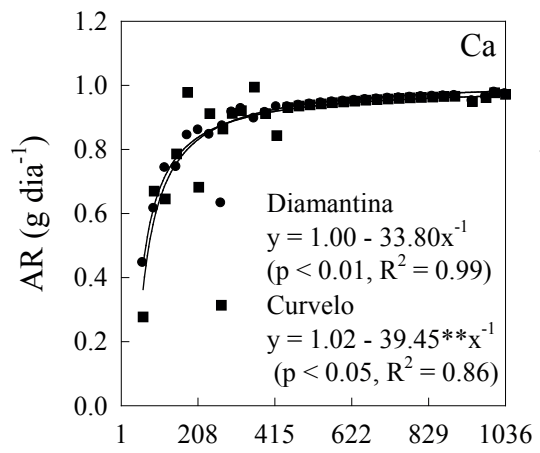

Days after planting

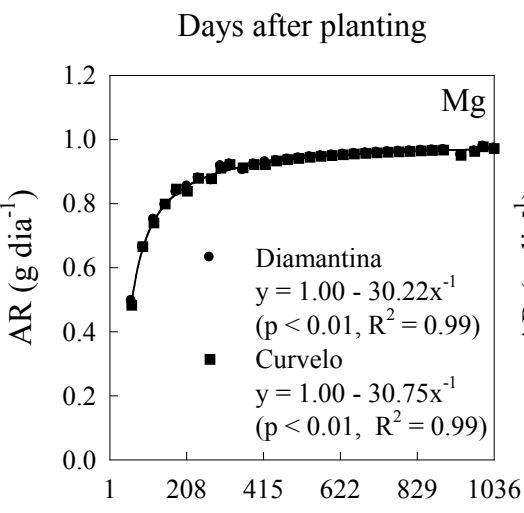

Days after planting

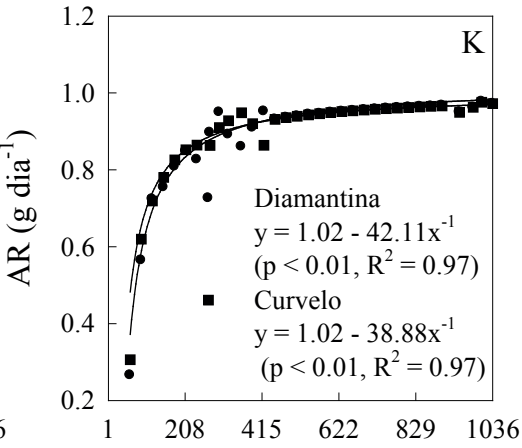

Days after planting

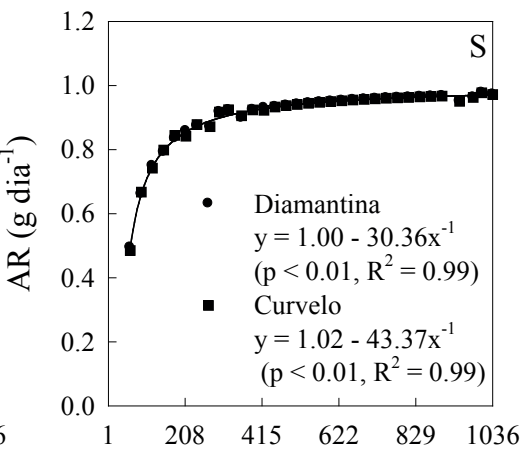

Days after planting 


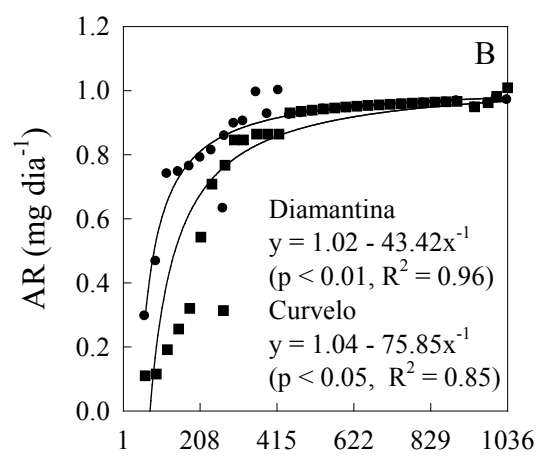

Days after planting

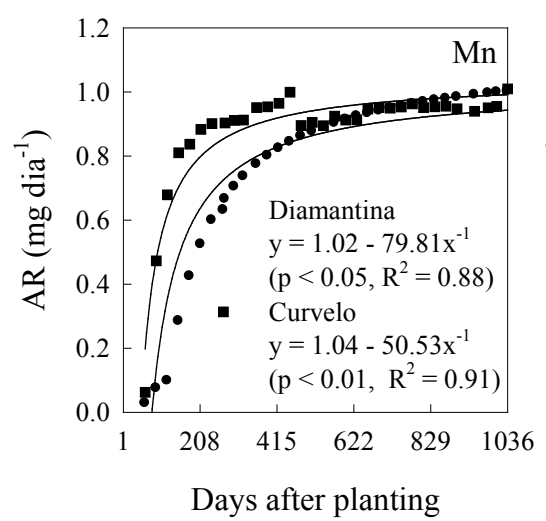

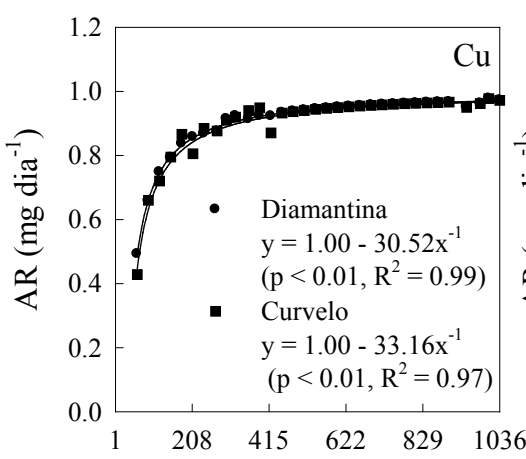

Days after planting

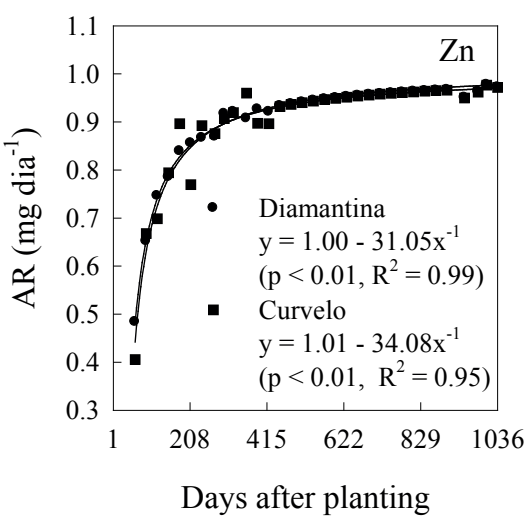

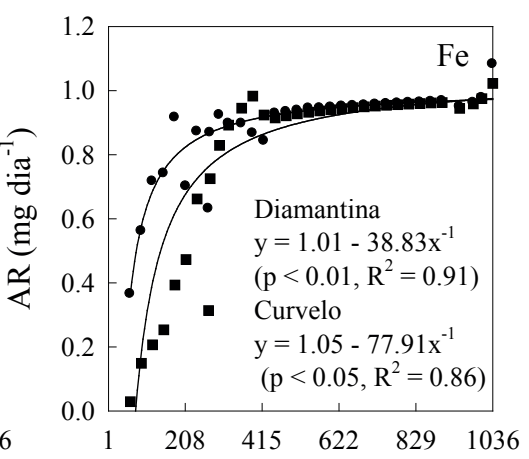

Days after planting

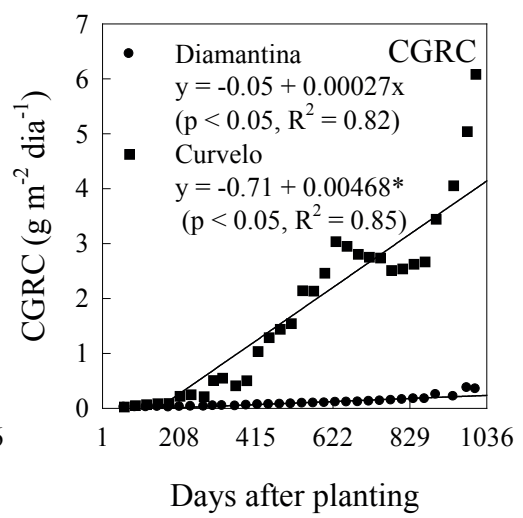

With regard to the absorption rates, it was possible to observe that, in general, physic nut presented a better response to initial fertilization (planting), due to the initial peak up to 208 DAP, later tending to stabilize and at the end of the experiment a slight increase in absorption rate. The peak period occurred between June and December 2010 , coinciding with the beginning of the most accentuated increase in the accumulated growth rate of the crop (CGRC) (Figure 5).

The absorption of nutrients differs according to the stage of development of the crop, intensifying in the flowering period and during the formation and growth of the fruit or of the organ that will be harvested. Therefore, in addition to considering the amount of nutrients absorbed, their concentration at different stages of development should be taken into account (MALAVOLTA et al., 1997).

The macronutrient extraction sequence differed at the two cultivation sites, but it was the same in the different plants parts, namely the leaf, stem and shoot. The order of accumulation of the macronutrients in the shoot at 1036 DAP was, $\mathrm{K}>\mathrm{Ca}>\mathrm{N}>\mathrm{P}>\mathrm{S}>\mathrm{Mg}$ in Diamantina and $\mathrm{N}>\mathrm{Ca}>\mathrm{K}>\mathrm{P}>\mathrm{Mg}>\mathrm{S}$ in Curvelo (Figure 6). 
Figure 6. Accumulation of macronutrients ( $a$ and $b$ ) and micronutrients ( $c$ and $d$ ) in physic nut plants under two soil and climatic conditions (Diamantina and Curvelo) from Minas Gerais State, evaluated up to 1,036 days after planting of the seedlings.
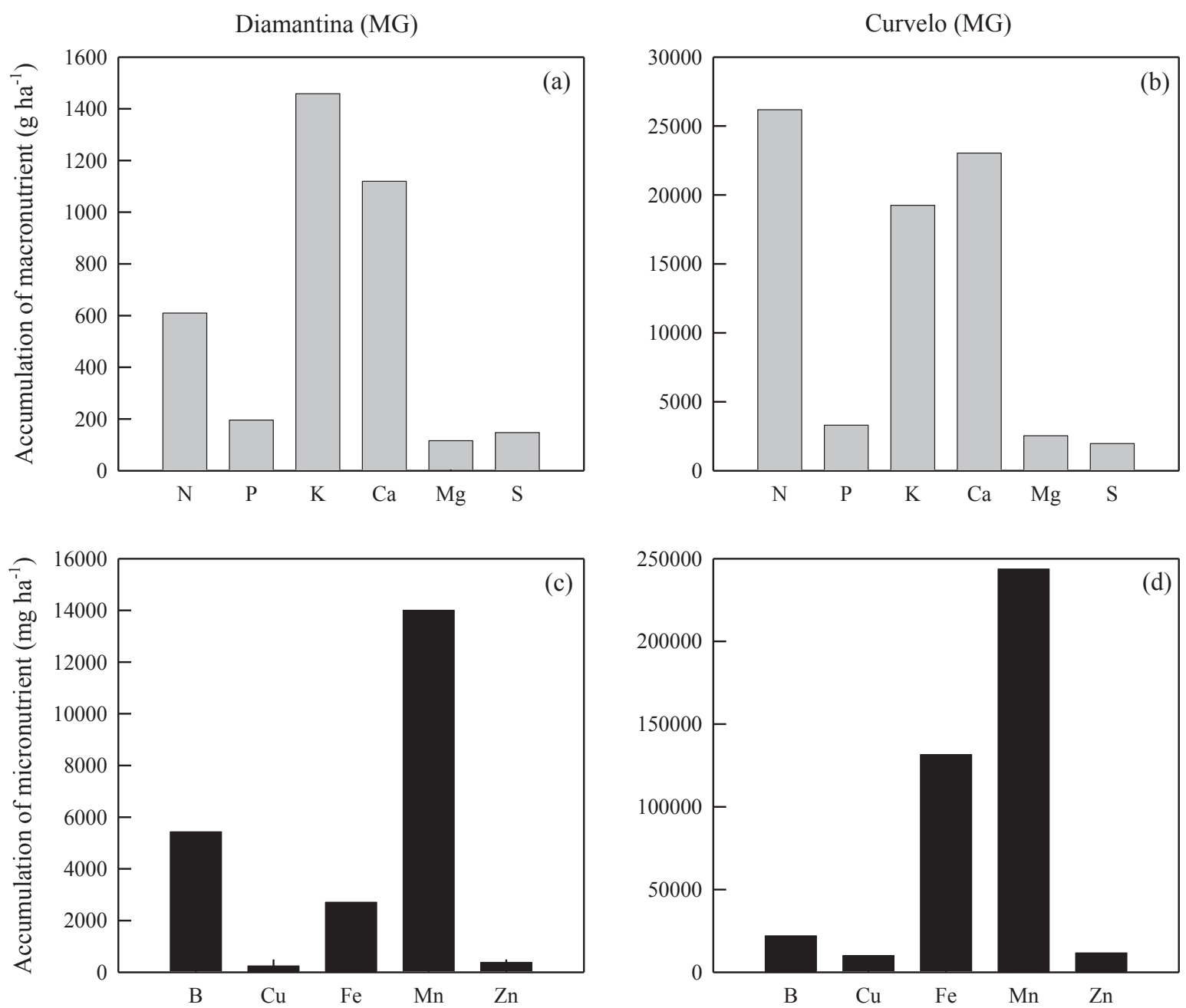

According to Malavolta et al. (1997), in general, most crops adhere to the order of macronutrient requirement, $\mathrm{N}>\mathrm{K}>\mathrm{Ca}>\mathrm{Mg}>\mathrm{P}>\mathrm{S}$. Physic nut plants presented a totally different order in Diamantina and a reversal of $\mathrm{Ca}$ in relation to $\mathrm{K}$ and between $\mathrm{Mg}$ and $\mathrm{P}$ in Curvelo, not maintaining the general tendency of most cultures.

In relation to the micronutrients, the accumulation in physic nut plants was also the same in the different parts of the plant, differing only according to the cultivation sites. $\mathrm{Mn}>\mathrm{B}>\mathrm{Fe}>\mathrm{Zn}>\mathrm{Cu}$ in Diamantina

and $\mathrm{Mn}>\mathrm{Fe}>\mathrm{B}>\mathrm{Zn}>\mathrm{Cu}$ in Curvelo (Figure 6) was the order of micronutrient accumulation in the shoot at 1036 DAP. The sequence of micronutrient accumulation found in Curvelo was similar to that observed by Laviola and Dias (2008) when studying nutrient accumulation in the physic nut plant.

According to Malavolta et al. (1997), in general, most crops adhere to the order of micronutrient requirement, $\mathrm{Fe}>\mathrm{Mn}>\mathrm{Zn}>\mathrm{Cu}>\mathrm{B}$, whereas physic nut plants showed an inversion of $\mathrm{Fe}$ in relation to $\mathrm{Zn}$ and $\mathrm{Cu}$ and between $\mathrm{Mn}$ and $\mathrm{B}$ when cultivated 
in Diamantina, and of $\mathrm{B}$ in relation to $\mathrm{Zn}$ and $\mathrm{Cu}$ and between $\mathrm{Mn}$ and $\mathrm{Fe}$ in Curvelo, not maintaining the general tendency of most cultures.

In a report by Silva et al. (2010), the order of limitation of the production of total dry matter in physic nut plants was $\mathrm{Ca}>\mathrm{Mg}>\mathrm{K}>\mathrm{N}>\mathrm{P}>\mathrm{S}$ for macronutrients and $\mathrm{Fe}>\mathrm{Cu}>\mathrm{Zn}>\mathrm{Mn}>\mathrm{B}$ for micronutrients.

\section{Conclusions}

The accumulation of macro and micronutrientes in physic nut plants was more pronounced in the edaphoclimatic conditions of Curvelo compared to plants cultivated in Diamantina.

The macronutrient extraction sequence differed at the two cultivation sites, but it was the same in the different parts of the plant, namely the leaf, stem and shoot. The order of accumulation of the macronutrients in the shoot at 1036 DAP was $\mathrm{K}>\mathrm{Ca}>\mathrm{N}>\mathrm{P}>\mathrm{S}>\mathrm{Mg}$ for Diamantina and $\mathrm{N}>\mathrm{Ca}>\mathrm{K}>\mathrm{P}>\mathrm{Mg}>\mathrm{S}$ for Curvelo.

The micronutrient extraction sequence showed differences between the two cultivation sites, however, it was the same in the different parts of the plant, namely the leaf, stem and shoot. The order of accumulation of micronutrients in the shoot at 1036 DAP was $\mathrm{Mn}>\mathrm{B}>\mathrm{Fe}>\mathrm{Zn}>\mathrm{Cu}$ in Diamantina and $\mathrm{Mn}>\mathrm{Fe}>\mathrm{B}>\mathrm{Zn}>\mathrm{Cu}$ in Curvelo.

\section{Acknowledgments}

We would like to thank the Minas Gerais Research Support Foundation (FAPEMIG) and the National Council for Scientific and Technological Development (CNPq) for financial support. The Coordination for the Improvement of Higher Education Personnel (Capes) for the masters scholarship. The Federal University of the Jequitinhonha and Mucuri Valleys for providing the necessary infrastructure for conducting the experiment.

\section{References}

ALBUQUERQUE, F. A.; ARRIEL, N. H. C.; BELTRÃO, N. E. de M.; LUCENA, A. M. A.; SOUZA, S. L.; FREIRE, M. A. O.; SAMPAIO, L. R. Análise de crescimento inicial do Jatropha curcas em condições de sequeiro. Revista Brasileira de Oleaginosas e Fibrosas, Campina Grande, v. 13, n. 3, p. 99-106, 2009.

ALVAREZ V., V. H.; RIBEIRO, A. C. Calagem. In: RIBEIRO, A. C.; GUIMARÃES, P. T. G.; ALVAREZ V., V. H., Recomendação para o uso de corretivos $e$ fertilizantes em Minas Gerais. $5^{a}$ aproximação. Viçosa, MG: CFSEMG, 1999. 359 p.

ANDRÉO-SOUZA, Y.; PEREIRA, A. L.; SILVA, F.; RIEBEIRO-REIS, R. C.; EVANGELISTA, M. R. V.; CASTRO, R. D.; DANTAS, B. Efeito da salinidade na germinação de sementes e no crescimento inicial de mudas de pinhão-manso. Revista Brasileira de Sementes, Viçosa, v. 32, n. 2, p. 83-92, 2010.

AVELAR, R. C.; SILVA, F. M.; CASTRO NETO, P.; FRAGA, A. C. Avaliação do desenvolvimento de pinhãomanso (Jatropha curcas L.) do Banco de Germoplasma da UFLA. In: CONGRESSO BRASILEIRO DE PLANTAS OLEAGINOSAS, ÓLEOS, GORDURAS E BIODIESEL, CLINICA TECNOLOGICA EM BIODIESEL, BIODIESEL: TECNOLOGIA LIMPA, 5. 2008, Lavras. Anais... Lavras: Universidade Federal de Lavras, 2008. p. 2796-2801.

HAAG, H. P.; MONTEIRO, F. A.; WAKAKURI, P. Y. Frutos de goiaba (Psidium guayava L.): Desenvolvimento e extração de nutrientes. Scientia Agricola, Piracicaba, v. 50, n. 3, p. 413-418, 1993.

LAVIOLA, B. G.; DIAS, L. A. S. Teor e acúmulo de nutrientes em folhas e frutos de pinhão-manso. Revista Brasileira Ciência do Solo, Viçosa, MG, v. 32, n. 5, p. 1969-1975, 2008.

LIMA, R. L. de; SEVERINO, L. S.; CAZETTA, J. O.; AZEVEDO, C. A. V. de; SOFIATTI, V.; ARRIEL, N. H. C. Redistribuição de nutrientes em folhas de pinhãomanso entre estádios fenológicos. Revista Brasileira de Engenharia Agrícola e Ambiental, Campina Grande, v. 15 , n. 11, p. 1175-1179, 2011a.

LIMA, R. L.; SEVERINO, L. S.; FERREIRA, G. B.; SOFIATTI, V.; SAMPAIO, L. R.; BELTRÃO, N. E. de M. Casca de mamona associada a quatro fontes de matéria orgânica para a produção de mudas de pinhãomanso. Revista Ceres, Viçosa, MG, v. 58, n. 2, p. 232237, 2011b.

MALAVOLTA, E.; VITTI, G. C.; OLIVEIRA, S. A. Avaliação do estado nutricional das plantas: princípios e aplicações. 2. ed. Piracicaba: POTAFOS, 1997. 319 p. 
MATTOS JÚNIOR, D.; QUAGGIO, J. A.; CANTARELlA, H.; ALVA, A. K. Nutrient content of biomass components of Hamlin sweet orange trees. Scientia Agricola, Piracicaba, v. 60, n. 1, p. 155-160, 2003.

NASCIMENTO, M. S. do; CRUSCIOL, C. A. C.; FERNANDES, A. M.; ZANOTTO, M. D. Nutrient extraction and exportation by castor bean hybrid lyra. Revista Brasileira de Ciência do Solo, Viçosa, MG, v. 36, n. 1, p. 123-124, 2012.

NOVAIS, R. F. de; ALVAREZ, V. H.; BARROS, N. F.; FONTES, R. L. F.; CANTARUTTI, R. B.; NEVES, J. C. L. Fertilidade do Solo. Viçosa, MG: Sociedade Brasileira de Ciência do Solo, 2007. 1017 p.

NOVAIS, R. F.; SMYTH, T. J. Fósforo em solo e planta em condições tropicais. Viçosa, MG: Universidade Federal de Viçosa, 1999. 300 p.

PACHECO, D. D.; SATURNINO, H. M.; MENDES, L. D.; PRATES, F. B. S.; SOARES, F. R.; PAULA, T. O. M.; SOUZA, L. C. A. Produção de massa vegetal e composição mineral de plantas de pinhão-manso. CONGRESSO BRASILEIRO DE PESQUISA EM PINHÃO-MANSO, 1., 2009, Brasília. Anais... Brasília: Embrapa Cerrados, 2009. p. 1-4.

PREZOTTI, L. C. Fertilização do cafeeiro. In: ZAMBOLIM, L. Tecnologias de produção de café com qualidade. Viçosa, MG: Universidade Federal de Viçosa, 2001. p. 607-615.

RITCHIE, S. W.; HANWAY, J. J.; BENSON, G. O. Como a planta de milho se desenvolve. Piracicaba: POTAFOS, 2003. 20 p. (Informações Agronômicas, 103).
SANTOS, S.; FERREIRA JÚNIOR, E. J.; PIRES, B.; NETTO, A. P. C. Efeito de diferentes adubações no desenvolvimento inicial de mudas de pinhão-manso (Jatropha curcas L.). In: CONGRESSO BRASILEIRO DE PLANTAS OLEAGINOSAS, ÓLEOS, GORDURAS E BIODIESEL, 4., 2007, Varginha. Anais... Lavras: Universidade Federal de Lavras, 2007. p. 547-554.

SILVA, E. B.; TANURE, L. P. P.; SOUZA, P. T.; GRAZZIOTTI, P. H.; SILVA, A. C. Crescimento de pinhão-manso em Neossolo Quartzarênico usando a técnica do nutriente faltante. Revista Brasileira de Oleaginosas e Fibrosas, Campina Grande, v. 14, n. 2, p. 73-81, 2010.

SILVA, E. B.; TANURE, L. P. P.; SANTOS, S. R.; RESENDE JÚNIOR, P. S. Sintomas visuais de deficiências nutricionais em pinhão-manso. Pesquisa Agropecuária Brasileira, Brasília, v. 44, n. 4, p. 392-397, 2009.

SILVA, F. C. Manual de análises químicas de solos, plantas e fertilizantes. 2. ed. Brasília: EMBRAPA Informações Tecnológicas, 2009. 627 p.

SILVA, J. T. A.; COSTA, E. L.; SILVA, I. P.; MOURA NETO, A. Adubação do pinhão-manso (Jatropha curcas L.) com nitrogênio e fósforo. In: CONGRESSO BRASILEIRO DE PLANTAS OLEAGINOSAS, ÓLEOS, GORDURAS E BIODIESEL, 4., 2007, Varginha. Anais... Lavras: Universidade Federal de Lavras, 2007. p. 1316-1320.

TAIZ, L.; ZEIGER, E. Fisiologia vegetal. 5. ed. Porto Alegre: Artmed, 2013. 954 p. 